DOI: https://doi.org/10.32838/2523-4803/70-3-50

УДК 336.74:336.763.33

\title{
Пластун О.Л.
}

доктор економічних наук, професор,

Сумський державний університет

Артеменко А.С.

аспірантка кафедри міжнародних економічних відносин,

Сумський державний університет

\section{Бочкарьова T.O.}

аспірантка кафедри фінансів, банківської справи та страхування,

Сумський державний університет

\section{Plastun Alex, Artemenko Alina, Bochkarova Tetiana}

Sumy State University

\section{ФАКТОР ВАЛЮТНОГО КУРСУ В МЕХАНІЗМІ ФУНКЦІОНУВАННЯ РИНКУ ОВДП В УКРАЇНІ}

\begin{abstract}
Статтю присвячено аналізу сучасних тенденцій на ринку облігаџій внутрішньої державної позики та валютному ринку, оцінці впливу основних факторів на зазначені сегменти фінансового ринку у контексті його безпеки. Основну увагу приділено дослідженню украӥнського ринку ОВДП та поточної боргової ситуації країни, того, як вона впливає на динаміку валютного курсу в краӥні та, навпаки, як валютний курс діє на поточну кон'юнктуру національного ринку облігачій. Оцінено взаємозв'язок між основними індикаторами боргової та валютної безпеки шляхом моделювання взаємозв'язку між дохідністю ОВДП, валютним курсом та ключовими макроекономічними показниками. На основі побудованої кореляиійно-регресійної моделі та матриці парних коефіцієнтів кореляції зроблено висновки щзодо напрямів розвитку внутрішнього ринку облігаџій в країні з макроекономічною нестабільністю та волатильним валютним курсом із метою мінімізаиї тиску на фінансову безпеку держави.

Ключові слова: державні ичінні папери, облігації внутрішньої державної позики, облікова ставка, валютний курс, режим валютного курсу.
\end{abstract}

Постановка проблеми. У 2019 році український ринок облігацій стрімко почав рости завдяки активному попиту іноземних інвесторів на гривневі облігації внутрішньої державної (ОВДП). Разом із мінімальною участю НБУ на валютному ринку в рамках продовження політики його лібералізації це привело до короткострокового укріплення гривні. Проте події, що розгорнулися навесні 2020 року (обвал фондових ринків через розпад угоди ОПЕК+, пандемія COVID-19), суттєво похитнули стабільність світового фінансового ринку загалом і України зокрема. Як результат, дослідження поточних тенденцій на валютному та ринку ОВДП, а також факторів впливу на механізм їхнього функціонування набувають актуальності.

Аналіз останніх досліджень i публікацій. Питанню валютної та боргової безпеки держави приділяється увага багатьма вітчизняними науковцями. У аналітичному контексті ОВДП як фактор впливу на боргову безпеку України розглядають Н.С. Педченко, В.Ю. Стрілець та Л.А. Лугівська [1]. О.П. Заруцька [2] розглядає вплив ОВДП загалом на економіку України.

1 Матеріал підготовлено в рамках НДР «Моделювання та прогнозування поведінки фінансових ринків як інформаційний базис забезпечення фінансової стійкості та безпеки держави» № державної реєстрації 0117U003936»
Зокрема, авторка приділяє увагу структурі та динаміці розміщення ОВДП, трендам дохідності ОВДП на первинному та біржовому ринках, а також досліджує вплив макроекономічних показників на дохідність ОВДП. Незважаючи на значущість досліджень вищезазначених авторів, оцінка фінансового сектору України поки що найчастіше розглядається на теоретичному рівні, з використанням статистичного аналізу, але без моделювання.

Існує достатня кількість іноземних робіт, в яких аналізується взаємозв'язок валютного курсу з ринками державних облігацій. Особливо активно стали звертати на нього увагу з появою стратегії Керрі-трейд, за якої інвестори позичають у низькодохідній валюті для інвестування у високодохідні, оскільки валютні курси та процентні ставки різних країн різняться (C. Burnside, M. Eichenbaum, S. Rebelo) [3].

K. Miyajima, M. S. Mohanty, T. Chan [4] показали, що висока дохідність облігацій у національній валюті країн, що розвиваються, може бути зниженою високою волатильністю валютного курсу, а також відсутністю похідних цінних паперів, які б хеджували ризики, особливо в кризовий період.

Протилежної думки W. Gale та P. Orszag [5]. Вчені звертають увагу на те, що слабкіше фіскальне наванта- 
ження приводить до вищої дохідності за облігаціями, а V. Piljak тa L. Swinkels [6] стверджують, що макроекономічні фактори, поточна монетарна політика, рівень інфляції та фактори внутрішнього середовища є більш важливими. L. Jaramillo та A. Weber [7] підтвердили, що в умовах стабільності фіскальні умови не $є$ визначальними факторами формування рівня дохідності облігацій.

E. Baldacci та M. S. Kumar [8], T. Okimoto [9] дійшли висновку, що дефіцит бюджету і державний борг приводять до збільшення довгострокових процентних ставок, причому точна величина залежить від стану на світовому фінансовому ринку та поведінки інвесторів на ньому.

Sh. Peiris [10] довів, що розвинений внутрішній ринок облігацій сприяє фінансовій стабільності та економічному зростанню, а макроекономічна та фінансова нестабільність посилює зусилля розвивати їх як альтернативне джерело боргового фінансування державного та корпоративного секторів. При цьому іноземні інвестори можуть виступати своєрідними каталізаторами розвитку місцевих ринків облігацій.

L. Daniel [11] зробив висновки, що місцеві інвестори, як правило, купують та утримують облігації, тоді як іноземні схильні торгувати ними. Це сприяє пожвавленню ліквідності ринку. Або, навпаки, активна присутність іноземних інвесторів може привести до дестабілізації національного ринку облігацій внаслідок раптового припинення надходження іноземного капіталу. Особливо в зоні ризику країни, що розвиваються (G. Calvo та E. Talvi [12]).

Загалом рівень інтернаціоналізації ринків державних облігацій залежить від готовності іноземних інвесторів брати на себе валютні ризики, а також здатність нейтралізувати них. Облігації в національній валюті, на відміну від облігацій в іноземній, піддають інвесторів ризику несподіваної зміни обмінного курсу (P. Turner [13]).

Формулювання цілей статті. Основною метою статті $є$ дослідження сучасних тенденцій на ринку ОВДП та валютному ринку, а також оцінка впливу основних факторів на зазначені сегменти фінансового ринку у контексті його безпеки.
Виклад основного матеріалу. Основним індикатором валютної безпеки є обмінний курс національної валюти. Тому нижче розглянемо основні моменти, пов'язані з ним.

Незважаючи на макроекономічні та фінансові дисбаланси, українська гривня періодично знецінюється або укріплюється. Традиційно це пов'язують із фактором сезонності. Зазвичай укріплення відбувається у весняно-літній період, а послаблення - восени. Інформація про динаміку обмінного курсу гривні відносно долара США з 2010 року по I квартал 2020 року відображена на рис. 1.

За період 2009-2013 рр. курс тримався на рівні 7,90-7,99 грн/дол. США як наслідок дії режиму стабілізації валютного курсу для збереження контрольованості курсової динаміки та відновлення довіри до національної валюти. Проте у лютому 2014 року ситуація почала кардинально змінюватися, окільки країна перейшла до плаваючого режиму курсоутворення. Було введено жорсткі обмеження на проведення валютних операцій, знизився експорт товарів (на 13,5\% за 2014 р.), відбулася непередбачена зміна влади та розпочався воєнний конфлікт на території України [16]. Валютний курс досяг свого історичного піку і тримався у діапазоні 24-28 грн/дол. США до 2019 року. Останнім рекордом за попередні три роки став курс 23.46 грн/ дол. США у грудні 2019 року.

Це укріплення відбулося поступово й насамперед через: ріст попиту нерезидентів на гривневі ОВДП; стрімкий ріст цін на соняшникову олію та стабільність цін на зерно; значний оптимізм інвесторів і суспільства. Проте вже в березні 2020 року було встановлено новий антирекорд - 28,07 грн/дол. США. Негативна ситуація виникла внаслідок падіння на світових ринках цін на нафту та біржових індексів (розірвання домовленостей ОПЕК+, "чорний четвер" 12 березня 2020 року), масового скуповування населенням іноземної валюти в банках на фоні запровадження карантину із-за пандемії COVID-19; різкої зміни уряду України та втрати інтересу до українських ОВДП.

Вагомим фактором впливу на валютний курс в Україні є інфляція. На рис. 1 видно, що в Україні протягом останніх 10 років відбулися значні інфляційні коливання. Починаючи з 2009 р. рівень інфляції поступово зменшувався і в 2012 р. досягнув найнижчого значення за історію - 0,57\%. Але у квітні 2015 року девальвація гривні та різке підвищення цін і тарифів підняли індекс до пікового рівня $-48,7 \%$.

Щодо поточного стану, то СРI почав сповільнюватися з грудня 2018 i встановив новий рекорд у листопаді 2019 року - 5,1\%. Показник перевершив прогноз НБУ (6,3\%), який був опублікований в "Інфляційному звіті НБУ" за жовтень 2019 року [17]. Процесу дезінфляції сприяли виважена 
фіскальна політика, відносно низькі ціни на енергоресурси на світових ринках і зростання пропозиції продовольчих товарів завдяки підвищенню продуктивності сільськогосподарського виробництва.

Серед фінансових тенденцій України в 2019 році особливим був стрімкий ріст попиту на облігації внутрішньої державної позики в іноземних інвесторів. До літа 2019 року мало кого турбував стан ринку ОВДП та зростання частки нерезидентів серед їхніх покупців. Насамперед їх вплив став відчутним у зв'язку з черговими змінами на валютному ринку.

Статистика українського ринку ОВДП свідчить про те, що за останні три роки інвестори дійсно зацікавилися державними цінними паперами. Якщо станом на 2014 рік в обігу знаходилося ОВДП на суму 457,6 млрд грн, то до березня 2020 року обсяги зросли до 840,4 млрд грн.

В Україні ринок ОВДП активізувався з метою вирішення проблеми дефіциту бюджету, погашення державного та гарантованого державою боргу $(2,1$ трлн дол або 56,1 \% від ВВП) та пом якшення валютної вразливості державного боргу за рахунок збільшення частки боргу в національній валюті - гривні (див. рис. 2).

Додатковий попит створила висока дохідність ОВДП (у 2018 році Мінфін розміщував ОВДП з номінальною дохідністю вище 17,79\%), яка залежить від облікової ставки НБУ (у 2018 році показник був на рівні $18 \%$ ), а також запуск аукціонів ОВДП на Bloomberg. Однак з укріпленням гривні сповільненням інфляції НБУ поступово почав знижувати ставку. У 2019 році іiі було змінено п'ять разів, з 18\% до 13,5\%, і у березні 2020 року - до $10 \%$.

3 рис. 3 видно, що серед ОВдП, які знаходяться в обігу станом на 03.04.2020, переважають саме гривневі - 73\% у загальній структурі. На другому місці ОВДП у іноземній валюті з часткою $13 \%$.
Розглядаючи структуру ОВДП, відображену на рис. 4, можна помітити, що простежується монополія банківської системи на ринку ОВДП, що не дає змоги його достатнім чином диверсифікувати.

Зважаючи на те, що державні цінні папери є інструментом боргової і грошово-кредитної політики та можуть впливати на макроекономічні показники та загальну стабільність економіки, важливо дослідити міру цього впливу та існуючі взаємозв'язки. Такий аналіз дає можливість передбачити наслідки того чи іншого вектору політики відносно державних цінних паперів і за необхідності запропонувати його зміну.

Оскільки найпоширенішим 3 усіх видів державних цінних паперів на фондовому ринку є ОВДП, то i потенційний вплив на макроекономічну ситуацію може бути вагомим. Для того, щоб проаналізувати зв'язок між індикаторами ОВДП і макроекономічними показниками, розглянемо загальну динаміку обсягів ОВДП у власності нерезидентів і курсу гривні до дол. США (див. рис. 5-6). Можна простежити тенденцію до підвищення обсягів ОВДП у власності нерезидентів і зниження курсу гривні до дол. США (рис. 5).

3 03.01.2019 р. до 13.12.2019 р. обсяг ОВДП у власності нерезидентів зріс із 13,39 млрд. грн до 110,07 млрд. грн (на 722,03\%). За цей час валютний курс зменшився з 27,69 грн/дол. США до 23,56 грн/ дол. США (14,92\%).

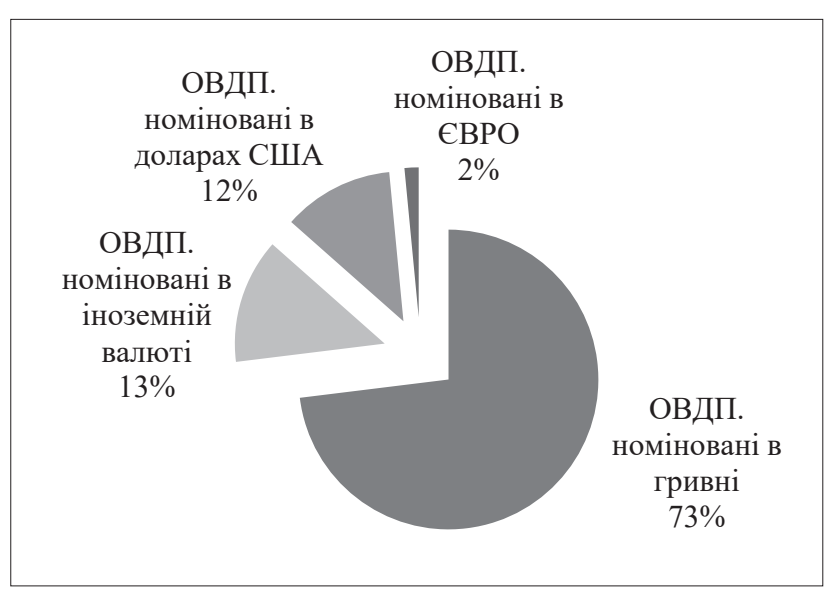

Рис. 3. ОВДП, які знаходяться в обігу, за видами цінних паперів (станом на 03.04.2020) [14]

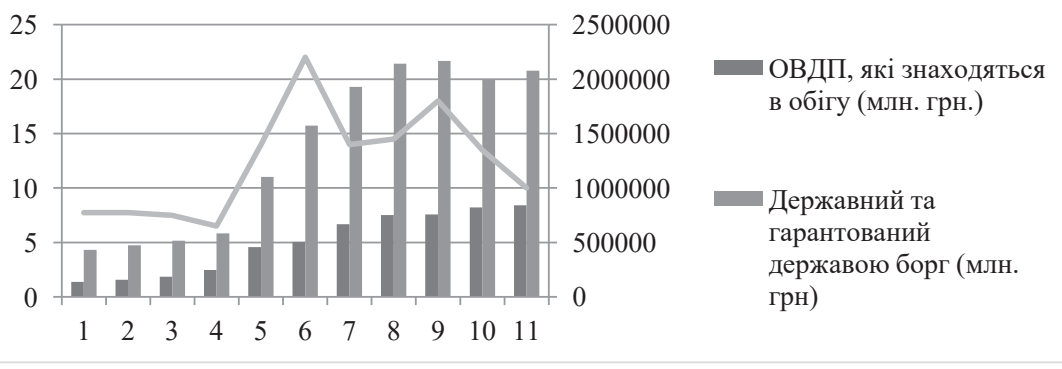

Рис. 2. Обсяг ОВДП, які знаходяться в обігу

в структурі державного боргу, та динаміка облікової ставки, 2010 - I квартал 2020 року [14-15; 18]

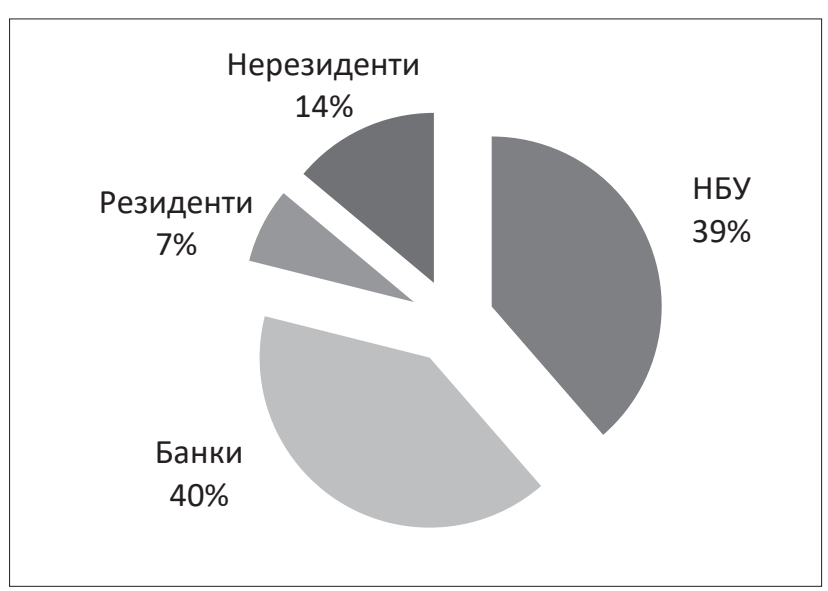

Рис. 4. ОВДП, які знаходяться в обігу, за видами власності (станом на 03.04.2020) [14] 


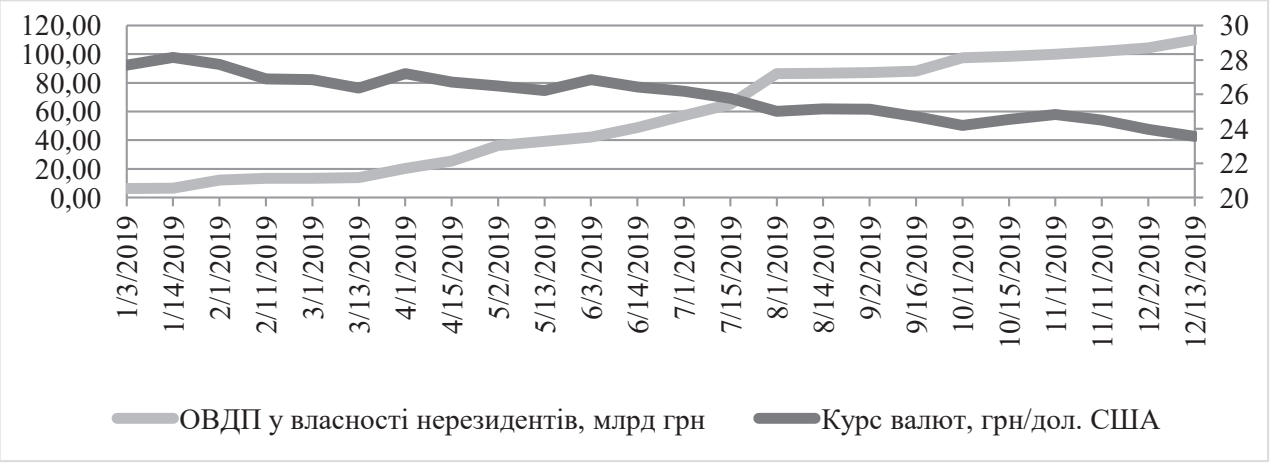

Рис. 5. Динаміка обсягів ОВДП у власності нерезидентів і курсу валют за 2019 р. Джерело: побудовано авторами на основі [19; 20]

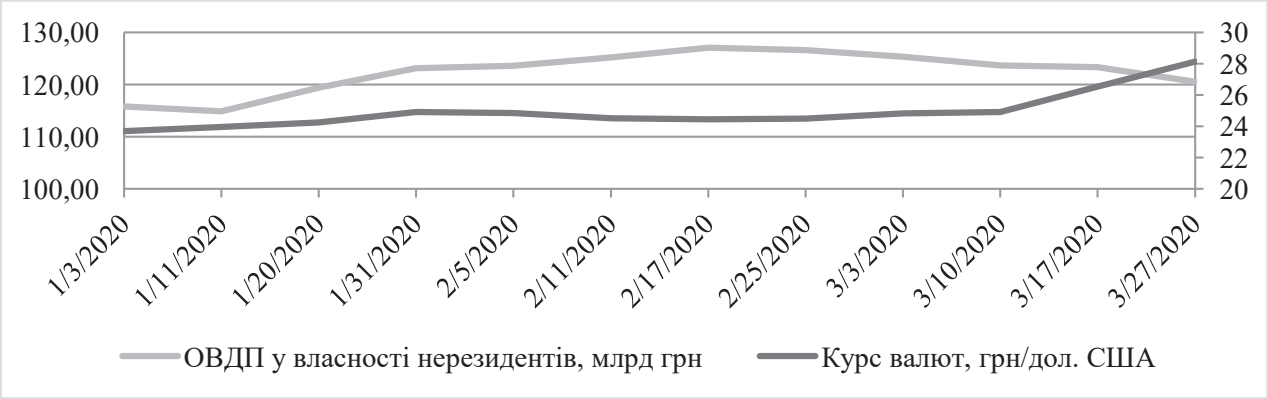

Рис. 6. Динаміка обсягів ОВДП у власності нерезидентів і курсу валют за I квартал 2020 року

Джерело: побудовано автором на основі [19; 20]

Різке збільшення обсягів ОВДП у власності нерезидентів з 03.02.2019 р. до 13.12.2019 р. відбулося у серпні. Так, значення за цим показником зросло 3 42,25 млрд грн у червні 2019 року до 86,41 млрд грн на початку серпня 2019 р. (на 104,52\% всього за 2 місяці). Відповідно, це мало вплив і на валютний курс. Курс гривні зменшився з 26,85 грн/дол. США до 25,02 грн/ дол. США (на 6,82\%).

У 2020 році обсяги ОВДП у власності нерезидентів продовжують зростати до лютого місяця, потім цей показник починає поступово знижуватися (див. рис. 6). Так, з кінця лютого 2020 року до кінця березня 2020 року обсяг ОВДП у власності нерезидентів знизився на 6 млрд грн, або на 4,78\%. Це пов'язано з тим, що власники боргових цінних паперів почали продавати їх на вторинному ринку через ризик дефолту в Україні, що виник із-за пандемії та карантину. Аналізуючи тенденції курсу валют, можемо констатувати, що курс гривні до дол. США досить чутливо зреагував на зазначені умови. Так, за період із кінця лютого до кінця березня 2020 року курс гривні до дол. США збільшився 3 24,50 грн/дол. США до 28,14 грн/дол. США (на 3,64 грн, або 14,85\%).

Таким чином, можна спостерігати спекулятивний вплив купівлі-продажу нерезидентами ОВДП на валютний курс гривні. Чим більші обсяги ОВДП зосереджуються у власності нерезидентів, тим нижчим стає курс, і навпаки. Тобто можна очікувати значну девальвацію національної валюти по відношенню до іноземних валют у період, коли власники-нерезиденти ОВДП почнуть масово продавати свої цінні папери.

Щоб підтвердити цей зв'язок математичними розрахунками, наводимо результати побудови матриці парних коефіцієнтів кореляції (див. табл. 1), поле кореляції (див. рис. 7) і рівняння регресії (формула 1). Цей період вибраний у зв'язку 3 описаними на початку статті подіями на ринку цінних паперів та валютному ринку. Також варто зазначити, що для більш широкого періоду, а саме 2014-2019 рр., тісного зв'язку між зазначеними нижче змінними не спостерігається.

За результатами побудови матриці парних коефіцієнтів кореляції для показників ОВДП у власності нерезидентів і курсу валют було отримано тісний зворотній зв'язок, котрий характеризується коефіцієнтом 0,6.

За результатами побудови поля кореляції показників обсягу ОВДП у власності нерезидентів і курсу валют за I квартал 2020 р. було отримано лінійну регресію. Цей зв'язок характеризується відповідним рівнянням і значенням коефіцієнта детермінації 0,74, що свідчить про високу міру залежності між наведеними величинами.

За даними цього рівняння можна зазначити, що за збільшення обсягу ОВДП у власності нерезидентів на 1 млрд грн курс валют зменшується на 0,74 грн/дол. США. Рівняння характеризується високою якістю, 
Таблиця 1

Матриця парних коефіціснтів кореляції для показників ОВДП у власності нерезидентів і курсу валют

\begin{tabular}{|l|c|c|}
\hline \multicolumn{1}{|c|}{ Показники } & Курс валют, грн/дол. США & ОВДП у власності нрезидентів, млрд грн \\
\hline Курс валют, грн/дол. США & 1 & \\
\hline ОВДП у власності нерезидентів, млрд. грн & -0.86 & 1 \\
\hline
\end{tabular}

Джерело: побудовано авторами

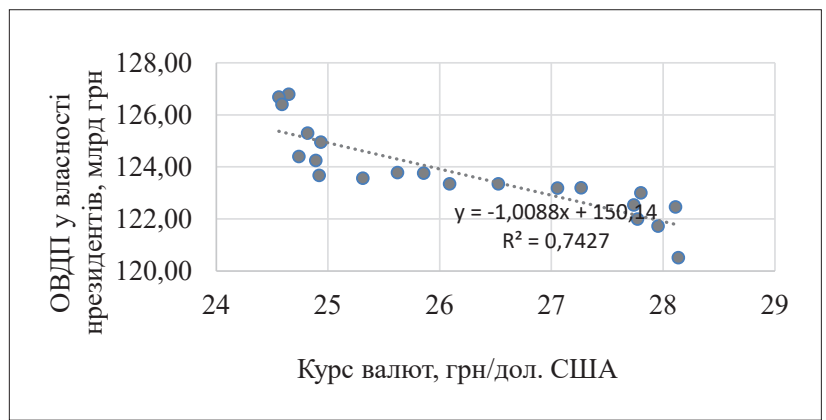

Рис. 7. Поле кореляції показників обсягу ОВДП у власності нерезидентів і курсу валют за I квартал 2020 р.

Джерело: побудовано авторами

адже коефіцієнт детермінації має високе значення і дорівнює 0,74. Зв'язок є істотним, тому що Ғфакт $(54,84)>$ Fтабл. $(3,18)$.

Результатом регресійного аналізу є рівняння регреciï, що відображає зв'язок між обсягами ОВДП у власності нерезидентів і курсом валют:

$$
y=117,27+x \cdot(-0,74),
$$

де у - курс валют, грн/дол. США,

х - обсяг ОВДП у власності нерезидентів, млрд грн.

Для виявлення зв'язку між важливими індикаторами ОВДП і макроекономічними показниками наводимо матрицю (табл. 2).

Результати побудови матриці парних коефіцієнтів кореляції для середньозваженої дохідності ОВДП і макроекономічних показали, що зв'язок між середньозваженою дохідністю ОВДП (до 1 року) і рівнем інфля- ції не є тісним та характеризується коефіцієнтом 0,39, зв'язок між середньозваженою дохідністю ОВДП (до 1 року) і відношенням дефіциту (профіциту) державного бюджету до ВВП також не є тісним та характеризується коефіцієнтом 0,20.

Варто відмітити досить тісний зв'язок між середньозваженою дохідністю ОВДП (до 1 року) і обліковою ставкою НБУ, значення парного коефіцієнта кореляції становить 0,97. А також між середньозваженою дохідністю ОВДП (до 1 року) і курсом гривні до дол. США - 0,93. Такого тісного зв'язку для середньозваженої дохідності ОВДП (від 5 років) не спостерігається.

Рівняння регресії, що відображає зв'язок між середньозваженою дохідністю ОВДП і обліковою ставкою НБУ:

$$
y=-19,29+1,17 \cdot x_{1}+0,64 \cdot x_{2}
$$

де у - середньозважена дохідність ОВДП, \%,

х1 - облікова ставка НБУ, \%,

х2 - курс грн до дол. США.

Отже, за збільшення облікової ставки НБУ на 1\% середньозважена дохідність ОВДП збільшиться на 1,17\%, а за збільшення курсу грн до дол. США на 1 п.п. на $0,64 \%$. Рівняння характеризується достатньою якістю, адже коефіцієнт детермінації дорівнює 0,96 . Зв'язок $є$ істотним, тому що $\mathrm{F}_{\text {факт }}(118,03)>\mathrm{F}_{\text {табл. }}(5,05)$.

Такий зв'язок пояснюється тим, що основою монетарною політики НБУ $є$ саме його облікова ставка. Збільшуючи чи зменшуючи іiі, НБУ впливає на кредитування реального сектору і створює сприятливі умови для залучення коштів в ОВДП. У свою чергу підвищення попиту на ОВДП має вплив на валютний курс.

Таблиця 2

Матриця парних коефіціснтів кореляції для середньозваженої дохідності ОВДП і макроекономічних показників

\begin{tabular}{|l|c|c|c|c|c|c|}
\hline \multicolumn{1}{|c|}{ Показники } & $\begin{array}{c}\text { Середньозважена } \\
\text { дохідність ОВДП } \\
\text { (до 1 року), \% }\end{array}$ & $\begin{array}{c}\text { Середньозважена } \\
\text { дохідість ОВДП } \\
\text { (від 5 років), \% }\end{array}$ & $\begin{array}{c}\text { Облікова } \\
\text { ставка } \\
\text { НБУ, \% }\end{array}$ & $\begin{array}{c}\text { Відношення грн } \\
\text { до дол. } \\
\text { США }\end{array}$ & $\begin{array}{c}\text { Рівень } \\
\text { інфляції, } \\
\text { \% } \\
\text { (профіциту) } \\
\text { державного } \\
\text { бюджету до } \\
\text { ВВП, \% }\end{array}$ \\
\hline $\begin{array}{l}\text { Середньозважена дохідність } \\
\text { ОВДП (до 1 року), \% }\end{array}$ & 1 & & & & \\
\hline $\begin{array}{l}\text { Середньозважена дохідність } \\
\text { ОВДП (від 5 років), }\end{array}$ & 0.00 & 1 & & & & \\
\hline Облікова ставка НБУ, \% & 0.97 & 0.12 & 1 & & & \\
\hline Курс грн до дол. США & 0.93 & -0.10 & 0.89 & 1 & & \\
\hline Рівень інфляції, \% & 0.39 & -0.64 & 0.33 & 0.35 & 1 & \\
\hline $\begin{array}{l}\text { Відношення дефіциту (профіциту) } \\
\text { державного бюджету до ВВП, \% }\end{array}$ & -0.20 & 0.36 & -0.16 & -0.28 & -0.36 & 1 \\
\hline
\end{tabular}

Джерело: побудовано авторами 
Для уникнення негативних наслідків такого напряму монетарної політики необхідним є створення умов для пожвавлення кредитування малого та середнього бізнесу України. Фінансові ресурси мають стати більш доступними для підприємців, що створить можливості для нарощення обертів економічного розвитку.

Висновки. Оцінка фінансового сектору України в розрізі валютного ринку та ринку ОВДП є актуальною у зв'язку з посиленням макроекономічної та фінансової нестабільності не тільки в нашій країні, а й у світі. Сучасний фінансовий ринок України характеризується високою часткою державного боргу, непередбачуваною волатильністю валютного курсу на фоні зниження інфляції та облікових ставок. Разом це створює певні умови, що формують відповідну поведінку інвесторів та інших учасників фінансового ринку, з одного боку, i держави - $з$ іншого.

Під час аналізу було виявлено тенденцію до підвищення обсягів ОВДП у власності нерезидентів і зниження курсу гривні до дол. США станом на 2019 рік. Також відмічено, помітне збільшення обсягів ОВДП у власності нерезидентів у серпні 2019 року. 3 кінця лютого 2020 року до кінця березня 2020 року обсяг ОВДП у власності нерезидентів, навпаки, знизився у зв'язку з їх продажем на вторинному ринку через ризик дефолту в Україні, внаслідок пандемії та карантину. Курс гривні до дол. США досить чутливо реагує на зазначені умови. Так, за період 3 кінця лютого до кінця березня 2020 року курс гривні до дол. США збільшився на $14,85 \%$. Таким чином, було доведено присутність спекулятивного ефекту, що вплинув на купівлю-продаж нерезидентами ОВДП на валютний курс гривні.

У роботі було математично підтверджено зв'язок між показниками ОВДП у власності нерезидентів і курсу валют. Зокрема, застосована матриця парних коефіцієнтів кореляції і регресійний аналіз. За допомогою розрахованого рівняння регресії стало зрозуміло, що за збільшення обсягу ОВДП у власності нерезидентів на 1 млрд грн курс валют зменшується на 0,74 грн/ дол. США. За допомогою аналізу зв'язку між індикаторами ОВДП і макроекономічними показниками було виявлено тісний зв'язок між середньозваженою дохідністю ОВДП і обліковою ставкою НБУ, а також між середньозваженою дохідністю ОВДП і курсом гривні до дол. США. Також за збільшення облікової ставки НБУ на 1\% середньозважена дохідність ОВДП збільшується на $1,17 \%$, а за збільшення курсу грн до дол. США на 1 п.п. - на 0,64\%.

\section{Список літератури:}

1. Педченко Н.С., Стрілець В.Ю., Лугівська Л.А. (2017). Ідентифікація стану боргової безпеки України на основі індикаторів та їх порогового значення. Науковий вісник Полтавського університету економіки і торгівлі. № 4 (82). c. 106-113.

2. Заруцька О.П. (2018). Облігації внутрішніх державних позик в Україні. Український соціум. № 1 (64). с. 74-94.

3. C. Burnside, M. Eichenbaum, and S. Rebelo. Carry Trade and Momentum in Currency Markets. Annual Review of Financial Economics (2014). № 3. 2011. 511-535 p. DOI: 10.1146/annurev-financial-102710-144913 (дата звернення: 01.05.2020).

4. K. Miyajima, M. S. Mohanty and T. Chan (2012). Emerging market local currency bonds: diversification and stability. BIS Working Papers. № 391. 35 p. URL: https://www.bis.org/publ/work391.pdf (дата звернення: 01.05.2020).

5. W. Gale, P. Orszag (2003). Economic Effects of Sustained Budget Deficits. National Tax Journal. № 56(3). 463-485 pp. URL: https://www.brookings.edu/wp-content/uploads/2016/06/20030717.pdf (дата звернення: 01.05.2020).

6. V. Piljak, L. Swinkels (2015). Frontier and Emerging Government Bond Markets. Emerging Markets Review, Forthcoming. 50 P. URL: https://ssrn.com/abstract=2610896 (дата звернення: 01.05.2020).

7. L. Jaramillo, A. Weber (2015). Bond Yields in Emerging Economies: It Matters What State You Are In. IMF Working Paper. № 198(12). 25 P. URL: https://www.imf.org/external/pubs/ft/wp/2012/wp12198.pdf (дата звернення: 01.05.2020).

8. E. Baldacci, M.S. Kumar (2013). Fiscal Deficits, Public Debt, and Sovereign Bond Yields. IMF Working Paper. № 184(10). 29 P. DOI: 10.5089/9781455202188.001 (дата звернення: 01.05.2020).

9. S. Kumar, T. Okimoto (2011). Dynamics of international integration of government securities' markets. Journal of Banking \& Finance. № 35(1). 142-154 pp. DOI: 10.1016/j.jbankfin.2010.07.019 (дата звернення: 01.05.2020).

10. Sh. Peiris (2010). Foreign Participation in Emerging Markets' Local Currency Bond Markets. IMF Working Paper. № 88(10). 20 P. URL: https://www.imf.org/external/pubs/ft/wp/2010/wp1088.pdf (дата звернення: 01.05.2020).

11. L. Daniel (2008). Foreign Investors' Participation in Emerging Market Economies' Domestic Bond Markets. Banque de France, Bulletin Digest. № 173. URL: https://publications.banque-france.fr/sites/default/files/medias/documents/ quarterly-selection-of-articles_12_2008-summer.pdf (дата звернення: 01.05.2020).

12. G. Calvo and E. Talvi. Süden Stop (2005). Financial Factors and Economic Collpase in Latin America: Learning from Argentina and Chile. NBER Working Paper Series. № 11153. DOI: 10.1093/acprof:oso/9780199534081.003.0008 (дата звернення: 01.05.2020).

13. P. Turner (2012). Weathering financial crisis: domestic bond markets in EMEs. BIS Papers. № 63. 20 P. URL: https://www.bis.org/publ/bppdf/bispap63e.pdf (дата звернення: 01.05.2020).

14. Сайт Національного банку України. URL: https://bank.gov.ua (дата звернення: 01.05.2020).

15. Сайт Державної служби статистики. URL: http://www.ukrstat.gov.ua/operativ/operativ2010/ct/bisc/bisc_u/arh_ bisc_u.htm (дата звернення: 01.05.2020).

16. Звіт про фінансову стабільність. НБУ. (2019). 50 C. URL: https://bank.gov.ua/news/all/zvit-pro-finansovustabilnist-gruden-2019-roku (дата звернення: 01.05.2020). 
17. Інфляційний звіт. НБУ. (2019). 45 C. URL: https://bank.gov.ua/admin_uploads/article/IR_2019_Q4.pdf?v=4 (дата звернення: 01.05.2020).

18. Сайт Міністерства фінансів України. URL: https://mof.gov.ua/uk/derzhavnij-borg-ta-garantovanij-derzhavju-borg (дата звернення: 01.05.2020).

19. Обсяги ОВДП у власності нерезидентів. НБУ. URL: https://bank.gov.ua/markets/t-bills (дата звернення: 01.05.2020).

20. Курс валют. Мінфін. URL: https://minfin.com.ua/ua/currency/usd/ (дата звернення: 01.05.2020).

\section{References:}

1. Pedchenko N.S., Strilets V.Yu., Luhivska L A. (2017). Identyfikatsiia stanu borhovoi bezpeky Ukrainy na osnovi indykatoriv ta yikh porohovoho znachennia. Naukovyi visnyk Poltavskoho universytetu ekonomiky i torhivli [Identification of the debt security state of Ukraine on the basis of indicators and their threshold value. Scientific Bulletin of Poltava University of Economics and Trade]. no 4 (82). p. 106-113.

2. Zarutska O.P. (2018). Oblihatsii vnutrishnikh derzhavnykh pozyk v Ukraini. Ukrainskyi sotsium [Domestic government bonds in Ukraine. Ukrainian society]. no 1 (64), p. 74-94.

3. C. Burnside, M. Eichenbaum, and S. Rebelo. Carry (2014) Trade and Momentum in Currency Markets. Annual Review of Financial Economics, no. 3 2011. 511-535 p. Available at: 10.1146/annurev-financial-102710-144913 (accessed: 01.05.2020).

4. K. Miyajima, M.S. Mohanty and T. Chan (2012). Emerging market local currency bonds: diversification and stability. BIS Working Papers. № 391.35 p. Available at: https://www.bis.org/publ/work391.pdf (accessed: 01.05.2020).

5. W. Gale, P. Orszag (2003). Economic Effects of Sustained Budget Deficits. National Tax Journal. № 56(3). 463-485 pp. Available at: https://www.brookings.edu/wp-content/uploads/2016/06/20030717.pdf (accessed: 01.05.2020).

6. V. Piljak, L. Swinkels (2015). Frontier and Emerging Government Bond Markets. Emerging Markets Review, Forthcoming. 50 P. Available at: https://ssrn.com/abstract=2610896 (accessed: 01.05.2020).

7. L. Jaramillo, A. Weber (2015). Bond Yields in Emerging Economies: It Matters What State You Are In. IMF Working Paper. № 198(12). 25 P. Available at: https://www.imf.org/external/pubs/ft/wp/2012/wp12198.pdf (accessed: 01.05.2020).

8. E. Baldacci, M.S. Kumar (2013). Fiscal Deficits, Public Debt, and Sovereign Bond Yields. IMF Working Paper. № 184(10). 29 P. Available at: 10.5089/9781455202188.001 (accessed: 01.05.2020).

9. S. Kumar, T. Okimoto (2011). Dynamics of international integration of government securities' markets. Journal of Banking \& Finance. № 35(1). 142-154 pp. Available at: 10.1016/j.jbankfin.2010.07.019 (accessed: 01.05.2020).

10. Sh. Peiris (2010). Foreign Participation in Emerging Markets' Local Currency Bond Markets. IMF Working Paper. № 88(10). 20 P. URL: https://www.imf.org/external/pubs/ft/wp/2010/wp1088.pdf (accessed: 01.05.2020).

11. L. Daniel (2008). Foreign Investors' Participation in Emerging Market Economies' Domestic Bond Markets. Banque de France, Bulletin Digest. № 173. Available at: https://publications.banque-france.fr/sites/default/files/medias/documents/ quarterly-selection-of-articles_12_2008-summer.pdf (accessed: 01.05.2020).

12. G. Calvo and E. Talvi. Sudden Stop (2005). Financial Factors and Economic Collpase in Latin America: Learning from Argentina and Chile. NBER Working Paper Series. № 11153. Available at: 10.1093/acprof:oso/9780199534081.003.0008 (accessed: 01.05.2020)

13. P. Turner (2012). Weathering financial crisis: domestic bond markets in EMEs. BIS Papers. № 63. 20 P. Available at: https://www.bis.org/publ/bppdf/bispap63e.pdf (accessed: 01.05.2020).

14. Sait Natsionalnoho banku Ukrainy [Website of the National Bank of Ukraine]. Available at: https://bank.gov.ua (accessed: 01.05.2020).

15. Sait Derzhavnoi sluzhby statystyky [Website of the State Statistics Service]. Available at: http://www.ukrstat.gov.ua/ operativ/operativ2010/ct/bisc/bisc_u/arh bisc_u.htm (accessed: 01.05.2020).

16. Zvit pro finansovu stabilnist. NBU [Financial Stability Report. NBU]. (2019). 50 C. Available at: https://bank.gov.ua/ news/all/zvit-pro-finansovu-stabilnist-gruden-2019-roku (accessed: 01.05.2020).

17. Infliatsiinyi zvit. NBU [Inflation report. NBU]. (2019). 45 C. Available at: https://bank.gov.ua/admin_uploads/article/ IR 2019 Q4.pdf? $=4$ (accessed: 01.05.2020).

18. Sait Ministerstva finansiv Ukrainy [Website of the Ministry of Finance of Ukraine]. Available at: https://mof.gov.ua/ uk/derzhavnij-borg-ta-garantovanij-derzhavju-borg (accessed: 01.05.2020).

19. Obsiahy OVDP u vlasnosti nerezydentiv. NBU [Volumes of IGLBs owned by non-residents. NBU]. Available at: https://bank.gov.ua/markets/t-bills (accessed: 01.05.2020).

20. Kurs valiut. Minfin [Exchange rate. Minfin]. Available at: https://minfin.com.ua/ua/currency/usd/ (accessed: 01.05.2020). 


\section{ФАКТОР ВАЛЮТНОГО КУРСА}

\section{В МЕХАНИЗМЕ ФУНКЦИОНИРОВАНИЯ РЫНКА ОВГЗ В УКРАИНЕ}

Статья посвящеена анализу современных тенденций на рынке облигаций внутреннего государственного займа и валютном рынке, оиенке влияния основных факторов на указанные сегменты финансового рынка в контексте его безопасности. Основное внимание сосредоточено на исследовании украинского рынка ОВГЗ, а также текущей долговой ситуации в стране, того, ак она влияет на динамику валютного курса в стране и, наоборот, как валютный курс действует на текущую конъюнктуру национального рынка облигаций. Исследована взаимосвязь между основными показателями долговой и валютной безопасности путем моделирования взаимосвязи между доходностью ОВГЗ, валютным курсом и ключевыми макроэкономическими показателями. На основе построенной корреляционно-регрессионной модели и матриць парных коэффициентов корреляции сделаны выводы относительно направлений развития внутреннего рынка облигаций в стране с макроэкономической нестабильностью и волатильным валютным курсом с иелью минимизации давления на финансовую безопасность государства.

Ключевые слова: государственные цееннье бумаги, облигаџии внутреннего государственного займа, учетная ставка, валютный курс, режим валютного курса.

\section{CURRENCY COMPOSITION OF UKRAINIAN GOVERNMENT BOND MARKET}

The article is devoted to the analysis of current trends on the domestic government bond market and the foreign exchange market. In addition, there was assessed the influence of the main factors on these segments of the financial market in the context of its security. In particular, the main focus is on the study of the Ukrainian government bond market and the current debt situation in the country. For instance, the effect of the current debt situation on the dynamics of the exchange rate in the country is researched and, conversely, the effect of the exchange rate on the current state of the national bond market. The relation between the main indicators of debt and foreign exchange security is studied. It is showed by the modeling of correlation between government bonds, exchange rates, and key macroeconomic indicators. Based on the constructed correlation-regression model and a matrix of pair correlation coefficients, conclusions regarding the development of the domestic bond market in a country with macroeconomic instability and a volatile exchange rate are drawn in order to minimize pressure on the financial security of Ukraine. As a result of the analysis, it was founded that the modern financial market of Ukraine is characterized by a high share of public debt, unpredictable exchange rate volatility against the background of lower inflation, and discount rates. It was mathematically confirmed the relation between government bonds owned by non-residents and the exchange rate. Above all, a matrix of paired correlation coefficients and regression analysis were used. The relation between important government bonds indicators and macroeconomic indicators was analyzed. In particular, based on the analysis of the relationship between domestic government bonds indicators and macroeconomic indicators, a close relationship was found between the weighted average yield of domestic government bonds (up to 1 year) and the National Bank of Ukraine discount rate, as well as between the weighted average yield of domestic government bonds and the UAH exchange rate to U.S. dollar. A regression model was built based on the identified relationship.

Key words: government bonds, domestic government bonds, discount rate, foreign exchange rate, foreign exchange regime. 